\title{
Gas Chromatography/Electron Ionization Mass Spectrometry
}

National Cancer Institute

\section{Source}

National Cancer Institute. Gas Chromatography/Electron Ionization Mass Spectrometry. NCI Thesaurus. Code C120687.

An analytical technique where gas chromatography is coupled with electron ionization mass spectrometry in order to separate, identify, and quantify substances in a sample. 